\title{
Development of Direct Instruction Learning Model on Entrepreneurship Subject at State Vocational High School (VHS) of Farming Development Padang
}

\author{
$1^{\text {st }}$ Leni Zahara \\ Padang State University \\ Padang \\ $3^{\text {rd }}$ Ganefri \\ Padang State University \\ Padang
}

\author{
$2^{\text {nd }}$ Azwar Ananda \\ Padang State University \\ Padang \\ $4^{\text {th }}$ Ridwan \\ Padang State University \\ Padang
}

\begin{abstract}
The purpose of this research was to investigate: 1) how did students of Vocational High School (VHS) utilize compulsory entrepreneurship education program as a media in entrepreneurship activity. 2) How development design learning model improve students' ability in entrepreneurial spirit at Vocational High School (VHS) of Farming. 3) How to plan, apply, evaluate, and improve entrepreneurial spirit value of students at Vocational High School (VHS) of Farming Development Padang. 4) How to de velop entrepreneurship learning model to improve entrepreneurial spirit value of students at Vocational High School (VHS) of Farming. This study used to research and development $(R \& D)$ development model and ADDIE design development model. Entrepreneurship Learning model that developed was direct instruction. A sample of this research was 106 students of Vocational High School (VHS) of Farming who consisted of class X.1.1, X.1.2, X.2.1, and X.2.2 by using purposive sampling. Practicality model test through teachers and students perception that measured by the questioner. Effectiveness entrepreneurship learning model test that developed through direct instruction which used performance test by comparing students' achievement who followed entrepreneurship learning directly. Based on the result of teacher perception research about learning model was stated in the good category.
\end{abstract}

Keywords : Development Learning Model, Direct Instruction, Entrepreneurship

\section{INTRODUCTION}

Education is a bridge for a human to avoid from proverty, because education can improve all of the potency in human beings to realize prosperous life dream. In this regard, the human need to get an education to the benefits life in future [2]. There is some level of education, one of them is Vocational High School(VHS).

Vocational High School (VHS) is a formal school under National Education Department, that has a purpose is to produce graduates who are ready to job field independently as an entrepreneur [1]. In line with the average of students' age which is still productive time to receive science and technology included entrepreneurships, then Vocational High School become more important to prepare graduates who ready in entrepreneur [6]..

Based on Data Central Bureau of Statistic (BPS) was found that unemployment rate was still higher, it could be seen from open unemployment (TPT) which was dominated by people who educated in Vocational High School (VHS) with total number 9, $05 \%$, and then Senior High School (SHS) was 8,17\%, and Diploma I/II/III was $7,49 \%$. It meant that Organizing of Vocational High School (VHS) that organize by province agency was not able to give positive appreciation towards entrepreneurship programs, therefore it was needed to add the entrepreneurship program in Curriculum of Vocational High School (VHS) to produce capable graduates in mastering and developing life problem independently, creative spirit to find solution and solve this problem, independent spirit and did not depend on other [4]. .

Developing entrepreneurial spirit at Vocational High School of Farming Development of Padang in field of agriculture is a point wanted to get in entrepreneurship learning, through applying of entrepreneurship life skill and by using this approach : 1) Reorientation learning 2) Development of school culture, 3) development of school management and synergistic with society [3].

State Vocational High School (VHS) of Farming Development of Padang is the only one of farming school in Padang that specify in agriculture and has a purpose of producing technical personal who master in farming skill, entrepreneurial spirit, agribusiness insightful.

Entrepreneurships is a compulsory education program that related to entrepreneurship skill. Entrepreneurship skill can be seen from curriculum development in Vocational High School (VHS) of Farming and have to be able to organize and develop well [6]. Many positive advantages that can be 
taken from these such as, creating independence economically, and social values development for learners [5].

The number of students in Vocational High School (VHS) of Farming Development of Padang is increased. In academic year 2015/2016, a total number of students is 235 students. Based on observation and data that was gotten from Administration in 2016, High School (VHS) of Farming Development of Padang was found some problem as followed : 1) Rules of Education and Culture Ministry about imple mentation of the curriculu m of entrepreneurship subject was eliminated from 2 hours to 3 hours and it stressed to theory than real practice. 2) Incompatibility between study program, curriculum 2013, and material learning that had given at entrepreneurship subject, agribusiness study program and plant production but in fact students learned about ornamental fish at class X, 2nd semester. Moreover, students at class XI, 1st semester learned about trout at entrepreneurship subject. At class XII, 1st semester students learned about aviculture and ranch. 3)Students apperception about entrepreneurship learning was useless because it just provides many theories. In another hand, Vocational High School was expected to give more practice than theory to increase students' low motivation towards entrepreneurship subject.

Based on some problems above, the researcher wanted to realize entrepreneurship subject as students' foundation to solve some problem above. For this reason, the researcher was interested in conducting research by entitling "Development of Direct Instruction Learning Model on Entrepreneurship Subject at State Vocational High School (VHS) of Farming Development of Padang."

Entrepreneurship is formation word from English, unternehmer in Germany, meanwhile in Indonesia is enterpreneur. The word of Entrepreneur is a word from French, enterpreneur, it means that adventure, take risk, contractor, entrepreneur (Person who attempt in a certain job), a creator who sell the creativity [5].

Entrepreneurship education in Vocational High School (VHS), will create students' mindset and paradigm "After graduating from school, they will be job seeker has changed to after graduating from school, they create a job field" [6]. Entrepreneurship learning in Vocational High School (VHS) is expected its graduates are able to create job field as result of attitude and independent mentality which useful later for their selves, other people, and the most important to improve the national development in minimizing unemployment rate because of narrowing of job field [7].

\section{DEVELOPMENT METHODOLOGY
This research used Research and} Development(R\&D) of Development model. The development model of ADDIE design. Entrepreneurship Learning model that developed Direct Instruction Model. A sample of this research was students' in Vocational High School of Farming Development of Padang with total number 106 students. It included class X.1.1, X.1.2, X.2.1, and X.2.2. Practicality model test through teachers and students perception that measured by the questioner. Effectiveness entrepreneurship learning model test that developed through direct instruction which used performance test by comparing students' achievement who followed entrepreneurship learning directly.

\section{RESULT}

The final product of this development is in the form of an entrepreneurial learning model book, containing all aspects of the entrepreneurial learning model, including important material from entrepreneurial learning as well as an entrepreneurial learning model book for teachers containing work manuals used by teachers in the learning process. The book of entrepreneurship learning model for students is a work manual used by students in the learning process as student work sheet.

IV. DISCUSSION

Based on the result of teacher perception research about learning model was stated in the good category because direct instruction learning model has fulfilled five basic elements of learning models. Five basic elements according to Joyce and Weil (2009) are 1) Syntax is leaning operational steps. 2) The social system is the situation and the prevailing norm in learning 3 ) principle of reaction, describing how teacher considers, treat, and respond to students. 4) support system, all of advice, materials, and tools or environment that support learning. 5) instruction and nurturant effects - the result of learning that obtains is directly proportional based on purpose has been established (instructional effects) and the result of learning that unstructured is also in line with learning need to improve students' competency in direct instruction at State Vocational High School (VHS) of Farming Development of Padang.

Development direct instruction used ADDIE development model that consisted of : 1) analyzing model development direct instruction's needs. 2) Designing model development direct instruction 3) Developing model development direct instruction, and 5) Doing an assessing towards the implementation of model development direct instruction.

Direct instruction model can use in learning after getting validity, practicality, and effectiveness assessment based on predefined criteria. The result of a development model that consisted of Development Direct Instructional Model Book, Teacher's book and student's book that had been stated in a valid category by Validator. Learning module of Aiken V 0.89 was a good category. Books with an average of 0.84 were valid. The result of the development of Learning model has stated practically automatically. The average score of Teacher's book was 0.89 and it is practical category meanwhile students' book had average score was 0.82 , and it was a very practical category.

The result of direct instruction model development was stated effective after assessed by effectiveness test with 
considering activeness aspect, attitude and students' achievement. By applying model, $\mathrm{p}$-value $=0.000<0.05$. it showed that there were significant differences between students' achievement in control and experiment class.

\section{CONCLUSION}

Based on finding and discussion of this study, it can be concluded that data of the result this research is better directly than the conventional model in entrepreneurship learning at students level. Therefore, it suggests for the teacher to use direct instruction model in entrepreneurship learning because it is a line with national education purpose. Students are more active to find various sources of learning independently (they do not depend on the teacher), so they are able to be more creative in direct instruction. For the next researcher, it is suggested to carry out further studies about applying and developing direct instruction learning model.

\section{REFERENCES}

[1] Kourilsky, M. L," Entrepreneurial thinking and behavior: What role the classroom? In C.A. Kent (Ed.), Entrepreneurship Education : Current Developments, Future Directions Westport, “" CN : Quorum Books, pp. 137-152,1990

[2] Hardy Loh Rahim and Noor Faizah Mohd Lajin, “ Social Entrepreneurship and Graduate Employability," Int J Academic Research of Social Science vol.1, no.1, pp.33-40, 2015.

[3] Hardy Loh Rahim and Razmi Chik, "Graduate Entrepreneurs Creation: A Case of Universiti Technologi MARA, Malaysia," Int. J.Aust Basic \& Appl. Sci., vol.8, no.23,pp. 15-20, 2014.

[4] Kourilsky, M. L," Entrepreneurship Education: Opportunity in Search of Curriculum," in Opinion Papers, vol.389347, p.25,1995.

[5] Uslay, Can., Teach, Richard D. and Schwartz, Robert G, "Promoting Entrepreneurship for Economic Development: A Cross-Cultural Analysis of Student Attitudes," J. Research in Marketing and Entrepreneurship,vol 4, pp. $101-118,2002$.

[6] Ganefri," The Development of Production-Based Learning Approach to Entrepreneurial Spirit for Engineering Students," Int.J. Asian Social Science, Vol. 9, No. 12, 2013.

[7] Naisbitt, J," The golden age of entrepreneurism shapes a new workplace order Trend Letter," Int .J. Sage .Citizenship, Social and Economics Education, vol. 13, no.22,pp. 1-4, 1994. 